\title{
The early larval development of the tropical reef lobster Enoplometopus antillensis Lütken (Astacidea, Enoplometopidae) reared in the laboratory
}

\author{
Fernando A. Abrunhosa 1; Max W. P. Santana ${ }^{2} \&$ Marcus A. B. Pires ${ }^{1}$ \\ ${ }^{1}$ Núcleo de Estudos Costeiros, Universidade Federal do Pará. Alameda Leandro Ribeiro, Aldeia, 68600-000 Bragança, Pará, \\ Brasil.E-mail: faraujo@ufpa.br; marcuspiresp@bol.com.br \\ 2 Universidade Federal do Ceará. Avenida Mister Hull, Pici, 60455-760 Fortaleza, Ceará, Brasil. \\ E-mail: max_ufc@hotmail.com.br
}

\begin{abstract}
The early stages of the tropical reef lobster Enoplometopus antillensis Lütken, 1865 were described and illustrated in detail from specimens reared in the laboratory. Ovigerous females were captured in their habitat, at a depth of about 15 meters and transported to the laboratory. The larvae were reared in a recirculation water tank for approximately 15 days and then transferred to four 10 liters aquariums. The larvae were fed on Artemia sp. nauplii. Microalgae Dunaliella viridis was added daily to the culture. The larvae moulted seven times progressing through the zoea VIII. Megalopa stage was not achieved. The intermoulting period of each stage averaged from eight to 12 days. Morphological comparisons with previous reports are briefly discussed.
\end{abstract}

KEY WORDS. Crustacean; larval description; morphology; ornamental.

RESUMO. Desenvolvimento dos estágios iniciais da lagosta de recife tropical Enoplometopus antillensis Lütken (Astacidea, Enoplometopidae) cultivada em laboratório. Os estágios iniciais da lagosta tropical Enoplometopus antillensis Lütken, 1865 foram descritos e ilustrados a partir de espécimes cultivados em laboratório. Fêmeas ovígeras foram capturadas em seu habitat, na profundidade cerca de 15 metros e transportadas para o laboratório. As larvas foram cultivadas em tanques de água recirculante por aproximadamente 15 dias e, então transferidas para quatro aquários (capacidade 10 litros). As larvas foram alimentadas com náuplios de Artemia sp. recém eclodidos. A microalga Dunaliella viridis AUTOR foi diariamente adicionada no cultivo. As larvas mudaram sete vezes alcançando o zoea VIII. O estágio megalopa não foi obtido. O período de intermuda de cada estágio variou de cerca de oito a 12 dias. Comparações morfológicas com trabalhos anteriores são brevemente discutidas.

PALAVRAS-CHAVE. Crustáceo; descrição larval; morfologia; ornamental.

The genus Enoplometopus A. Milne-Edwards, 1862 comprises 11 species, but only two are found in the Atlantic ocean, $E$. antillensis Lütken, 1865 and E. callistus Intès \& Le Loeuff, 1970 (Poupin 2003, Ahyong, \& O'MEally 2004). The first is the most common species found in the Atlantic and the only Enoplometopus lobster reported in the tropical West Atlantic (Poupin 2003).

The nomenclature and classification of this genus have been controversial, most likely due to its rarity and morphological similarities among related species which have been captured (Merino \& Lindrey 2003). Thus, the Enoplometopus have been classified as an astacidean, an axiid thalassinidean or a sister to the Fractosternalia + Homarida (AHYong \& O'MEALly 2004). However, recent revisions and studies on the phylogeny and molecular analyses have placed it in Enoplometopidae (Martin \& Davis 2001, Ahyong \& O'Meally 2004).

In recent years, there has been an increase in the aquarium trade industry (Penha-Lopes et al. 2006). The marine aquarists have recognized the Enoplometopus as a very appreciated ornamental species because of its dazzling coloration, economic value and high demand. Unfortunately, little information on larval and adult biology is available.

Because studies on the culture of ornamental decapods have improved scientific understanding, the larval development and proper culture technologies have been developed for several species (RHYNe et al. 2005). However, many attempts to culture various species of decapods have failed, one of which is the Enoplometopidae. Perhaps this is because only a few hobbyists have time and motivation to work on species resistant or difficult to culture. IWATA et al. (1991) reported the first attempt of Enoplometopus with the species E. occidentalis in culture, in which eight zoeal stages were achieved.

A relevant aspect to be considered is the study on morphological development of cultured lobster. Observation of larval crustaceans has contributed to the identification of new 
species and facilitated their biological studies. The present study describes and illustrates in detail the early larval stages of $E$. antillensis reared in the laboratory. Morphological comparisons with larvae of its congeneric species E. occidentalis previously described by IwaTA et al. (1991) are briefly discussed.

\section{MATERIAL AND METHODS}

Ovigerous females of $E$. antillensis were captured at Fortim Beach $\left(04^{\circ} 14^{\prime} \mathrm{S}, 37^{\circ} 43^{\prime} \mathrm{W}\right)$, Ceará, Brazil, at a $15 \mathrm{~m}$ depth. They were carethlly transported in small polyethylene bags with sea water. In the laboratory, females were placed in $60 \mathrm{l}$ aquariums with seawater (salinity 33-36\%o and $\mathrm{pH} 8.0$ ).

The larvae were reared in circular tanks with continuous water circulation similar to those used for culture of several species of spiny lobsters (KITTAKA 1994). The tanks were made with acrylic $(70 \mathrm{~cm} \varnothing$ and $30 \mathrm{~cm}$ depth). Larvae were maintained in this recirculation system at a density of 10 larvae/l for approximately 15 days and then transferred to four 101 aquariums at the same density. The larvae were fed with Artemia sp. nauplii. Microalgae Dunaliella viridis was added daily to the culture at a concentration of $150 \times 10^{4} \mathrm{cell} / \mathrm{ml}$, in order to maintain the water quality by recycling inorganic nutrients, fixing carbon dioxide and supplying dissolved oxygen to the aquaculture systems by its photosynthetic activities. Temperature, salinity and $\mathrm{pH}$ were monitored using a multi-parameter portable equipment and dissolved ammonium with a tetra ammonia kit. Salinity and temperature values in the culture were approximately $35 \%$ and $27-29^{\circ} \mathrm{C}$, respectively.

Exuviae and death larvae were preserved in a glycerol + ethylic alcohol 70\% (1:1) solution after each moulting. About 10 larvae and exuviae of each stage were dissected and illustrated.

The carapace length (CL) was measured from the ocular region to the posterior midpoint region of the carapace. The illustrations and measures of the larvae were made under a binocular Zeiss microscope equipped with a micrometer disc.

\section{RESULTS}

\section{Larval culture}

In the laboratory, hatched larvae were obtained from three females. The larvae hatch as a prezoea (Fig. 1) in which they persist for less than one hour but many prezoea failed to moult into zoea I. Moulting of the $1^{\text {st }}$ to the $2^{\text {nd }}$ stage occurred $7-12$ days after being placed in tanks; the $2^{\text {nd }}$ to the $3^{\text {rd }}$ and $3^{\text {rd }}$ to the $4^{\text {th }}$ stages averaged seven and eight days, respectively. The intermoulting period for the subsequent stages was not possible to determine accurately since the larvae were not reared individually. High mortality occurred on the $3^{\text {rd }}$ culture day in which approximately $60 \%$ of the larvae died.

Morphological malformations were frequently observed in the mouthpart of the zoeae and it appeared to be related to the individual adaptation to the laboratorial conditions. This fact needs to be researched.

\section{DESCRIPTION OF THE LARVAL STAGES \\ Zoea I (Fig. 2)}

Carapace (Fig. 2): length (CL) $1.89 \mathrm{~mm}(1.89-1.90 \mathrm{~mm})$ : rostrum long, straight and gutter shaped, surpassing antennal scale with 6+6 small denticles laterally; carapace smooth; eyes sessile.

Antennule (Fig. 10): elongate; unsegmented with four aesthetascs and one plumose subdistal seta.

Antenna (Fig. 11): propod lacking seta; exopod segmented distally showing 8-9+1 plumose setae; endopod shorter than exopod with three long plumose setae.

Maxillule (Fig. 12): exopodite with three setae; endopod 3 -segmented, distal segment with $2+2$ distal plumose setae, proximal and medial segments with two and two distal setae respectively; basal endite with two strong cuspidate setae and two plumose setae; coxal endite with $5+2$ plumose setae.

Maxilla (Fig. 13): scaphognathite with $4+1$ plumose setae; endopod well developed and 5-segmented, with 3,2,2,1,2 long plumose setae; basal and coxal endites bilobed with long and plumose setae (as illustrated).

First maxilliped (Fig. 14): endopod short, 4-segmented with 2,2,3,4 setae; basipod bearing eight setae; coxal endite with two setae, exopod with four natatory setae.

Second maxilliped (Fig. 15): endopod 4-segmented with $3,2,2,4$ setae, distal segment (one long spine and three terminal setae); basipod with four setae; exopod with four natatory setae.

Third maxilliped (Fig. 16): endopod 4-segmented, (proximal segment fused with basipod) with $2+2,3,2,2+2$ setae (one strong and three long terminal and one subterminal setae); basipod with four setae; exopod with four natatory setae.

Abdomen (Fig. 2): with six abdominal somites lacking spines, $6^{\text {th }}$ abdominal segment long and fused with telson.

Telson (Fig. 17): bifurcate showing an accentuated medial depression with $5+1$ plumose setae and one spine on each furcal branch.

\section{Zoea II (Fig. 3)}

Carapace (Fig. 3): Length (CL) $2.24 \mathrm{~mm}$ (1.23-2.25 mm): rostrum with $8+8$ small denticles laterally; carapace showing a pterigostomial spine elongate; eyes stalked.

Antennule (Fig. 18): with five aesthetascs and one plumose subdistal seta.

Antenna (Fig. 19): propod segmented with endopod with 1 small seta; exopod segmented distally showing 8-9+1 plumose setae; endopod shorter than exopod with three long plumose setae.

Maxillule (Fig. 20): exopodite with four setae; endopod 3-segmented; basal endite with two cuspidate and three plumose setae; coxal endite with nine plumose setae.

Maxilla: similar to the previous stage.

First maxilliped (Fig. 21): endopod short, 4-segmented with 2,2,3,4 setae; basipod bearing seven setae; coxal endite with five setae, exopod with four natatory setae. 


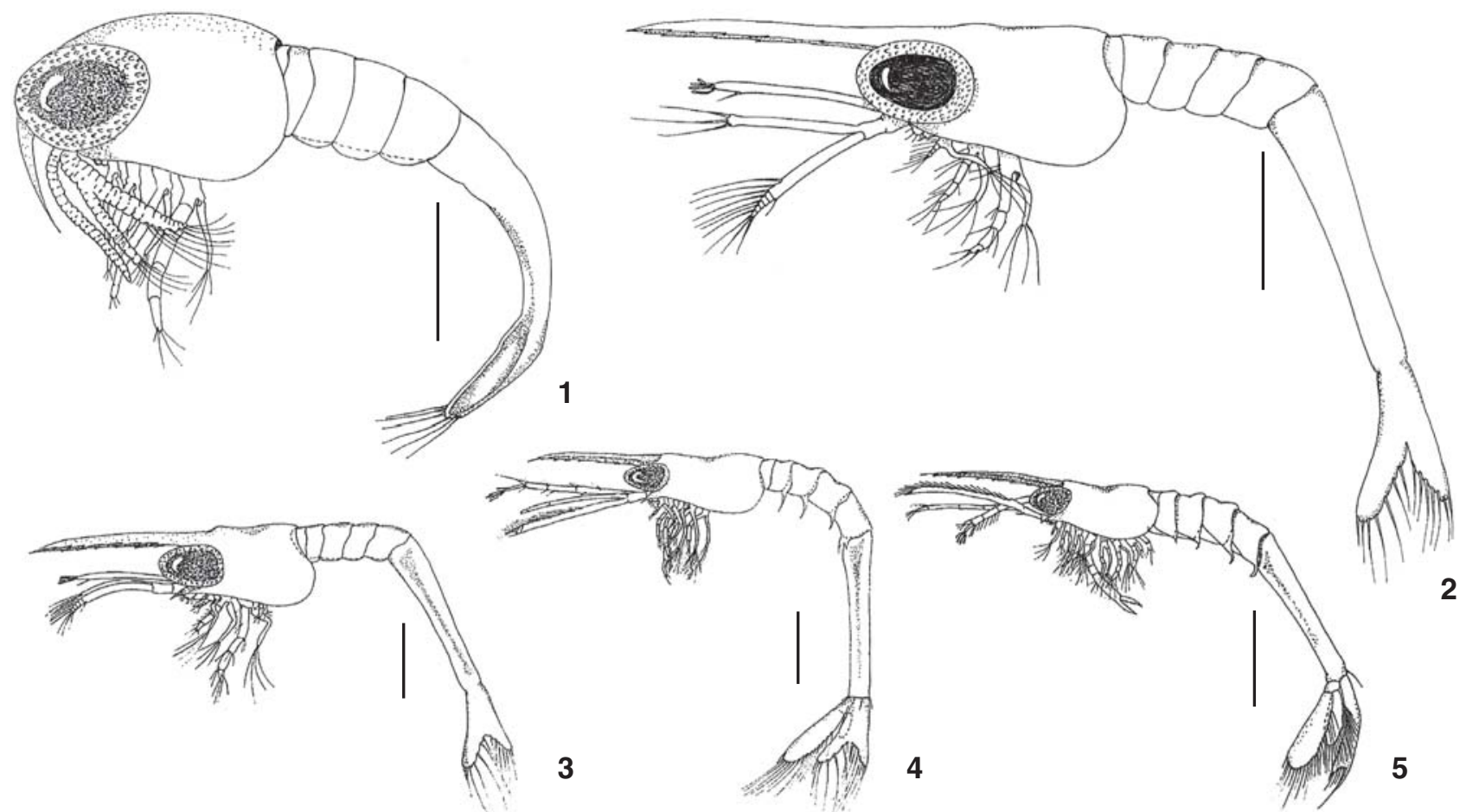

Figures 1-5. Enoplometopus antillensis, zoeal stages in lateral view: (1) prezoea; (2) stage I; (3) stage II; (4) stage III; (5) stage IV. Scale bar: $1-3=0.4 \mathrm{~mm}, 4=0.6 \mathrm{~mm}, 5=0.9 \mathrm{~mm}$.

Second maxilliped (Fig. 22): endopod 4-segmented with $3,2,2,4$ setae, distal segment (one long spine and three terminal setae); basipod with four setae.

Third maxilliped (Fig. 23): endopod 4-segmented with $1,5,4,5$ setae (one strong and three long terminal and one subterminal setae); basipod with four setae; exopod with five natatory setae.

First pereiopod (Fig. 24): rudimentary; endopod 2-segmented showing few setae; exopod small with 3-4 short distal setae.

Abdomen (Fig. 3): with six abdominal somites lacking spines, $6^{\text {th }}$ abdominal segment incompletely articulated with telson.

Telson (Fig. 25): bifurcate with $6+1$ plumose setae and one spine on each furcal branch.

\section{Zoea III (Fig. 4)}

Carapace (Fig. 4): length (CL) $1.96 \mathrm{~mm}(1.96-2.00 \mathrm{~mm})$; carapace unchanged; eyes stalked.

Antennule (Fig. 26): peduncle 3-segmented with 4-5 long lateral setae from first segment to distal portion of last segment; first segment longer than other about twice the length of the medial segment; outer flagellum unsegmented with six aesthetascs and one subdistal plumose seta; inner antennular flagellum unsegmented ending in one plumose and two simple setae.

Revista Brasileira de Zoologia 24 (2): 382-396, junho 2007
Antenna (Fig. 27): exopod 6-segmented with 18 plumose and one simple setae and strong lateral spine; endopod 3-segmented with three setae.

Maxillule (Fig. 28): endopod unchanged; basal endite with four strong cuspidate and five simple setae; coxal endite with $5+5$ plumose setae.

Maxilla (Fig. 29): scaphognathite with 14+1 long plumose setae; endopod unchanged; basal and coxal endites as illustrated.

First maxilliped (Fig. 30) and second maxilliped (Fig. 31): exopod with six natatory setae.

Third maxilliped (Fig. 32): exopod with 6-8 plumose setae.

First pereiopod (Fig. 33): endopod 4-segmented sub-chelate, arrangement of setation as illustrated; exopod with eight plumose setae.

Second pereiopod (Fig. 34): endopod developed and 4segmented, arrangement of setation as illustrated; exopod with eight setae.

Third pereiopod (Fig. 35): endopod developed and 4-segmented, arrangement of setation as illustrated; exopod with seven setae.

Fourth pereiopod (Fig. 36): bilobed and rudimentary with two setae.

Abdomen (Fig. 4): somites 1-3 each with pair of acute posterolateral spines, somite five with pair of bifurcate acute 


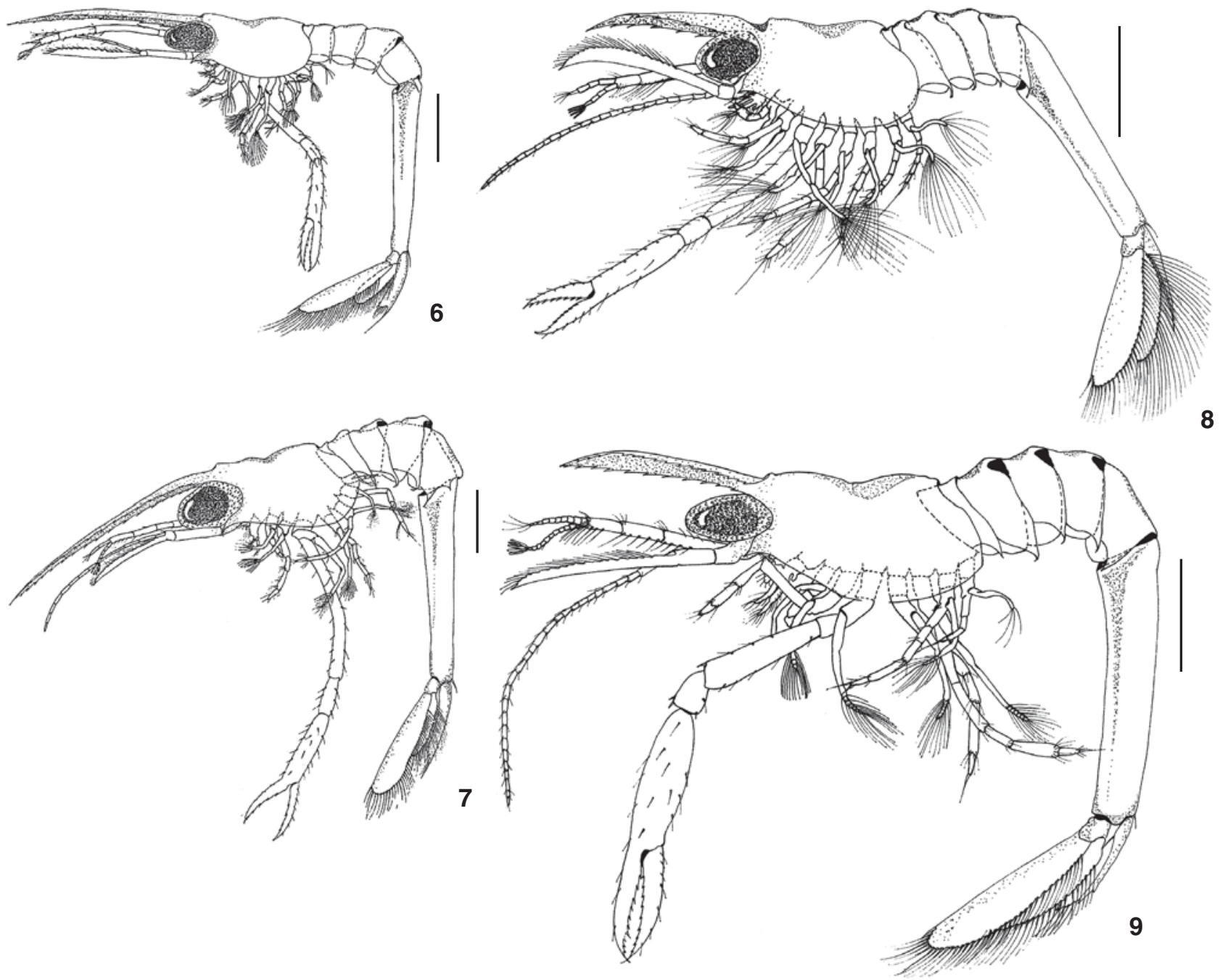

Figures 6-9. Enoplometopus antillensis, zoeal stages in lateral view: (6) stage V; (7) stage VI; (8) stage VII; (9) stage VIII. Scale bar: 6-7 = $0.6 \mathrm{~mm}, 8-9=1.2 \mathrm{~mm}$.

posterolateral spines; somite six articulated with telson bearing two small posterodorsal spines.

Telson (Fig. 37): posterior portion arcuated, with a strong and elongate median spine followed of $6+6$ inner setae and two strong spines on the outer margin; exopod with 14 plumose setae and one distal spine on outer margin; endopod with five plumose setae.

\section{Zoea IV (Fig. 5)}

Carapace (Fig 5): length (CL) $2.23 \mathrm{~mm}$ (2.10-2.35 mm): similar to the previous stage.

Antennule (Fig. 38): peduncle with first segment about three times the medial segment length, inner antennular flagellum a little more developed compared to previous stage.

Antenna (Fig. 39): exopod unsegmented with 22-23 plu- mose setae; endopod 5-segmented.

Maxillule (Fig. 40): basal endite with five strong serrulate and four simple setae; coxal endite with $3+6+2$ plumose setae.

Maxilla (Fig. 41): scaphognathite with $18-21$ plumose setae.

First maxilliped (Fig. 42): exopod with 4+2 natatory setae. Second maxilliped (Fig. 43): endopod 3-segmented, medial segment with a row of long setae distally; exopod with six natatory setae.

Third maxilliped (Fig. 44): endopod 4-segmented with distal segment ending in a strong spine surrounded by long setae; exopod with eight plumose setae.

First pereiopod (Fig. 45): endopod well developed 4-segmented, arrangement of setation as illustrated, chelipeds

Revista Brasileira de Zoologia 24 (2): 382-396, junho 2007 

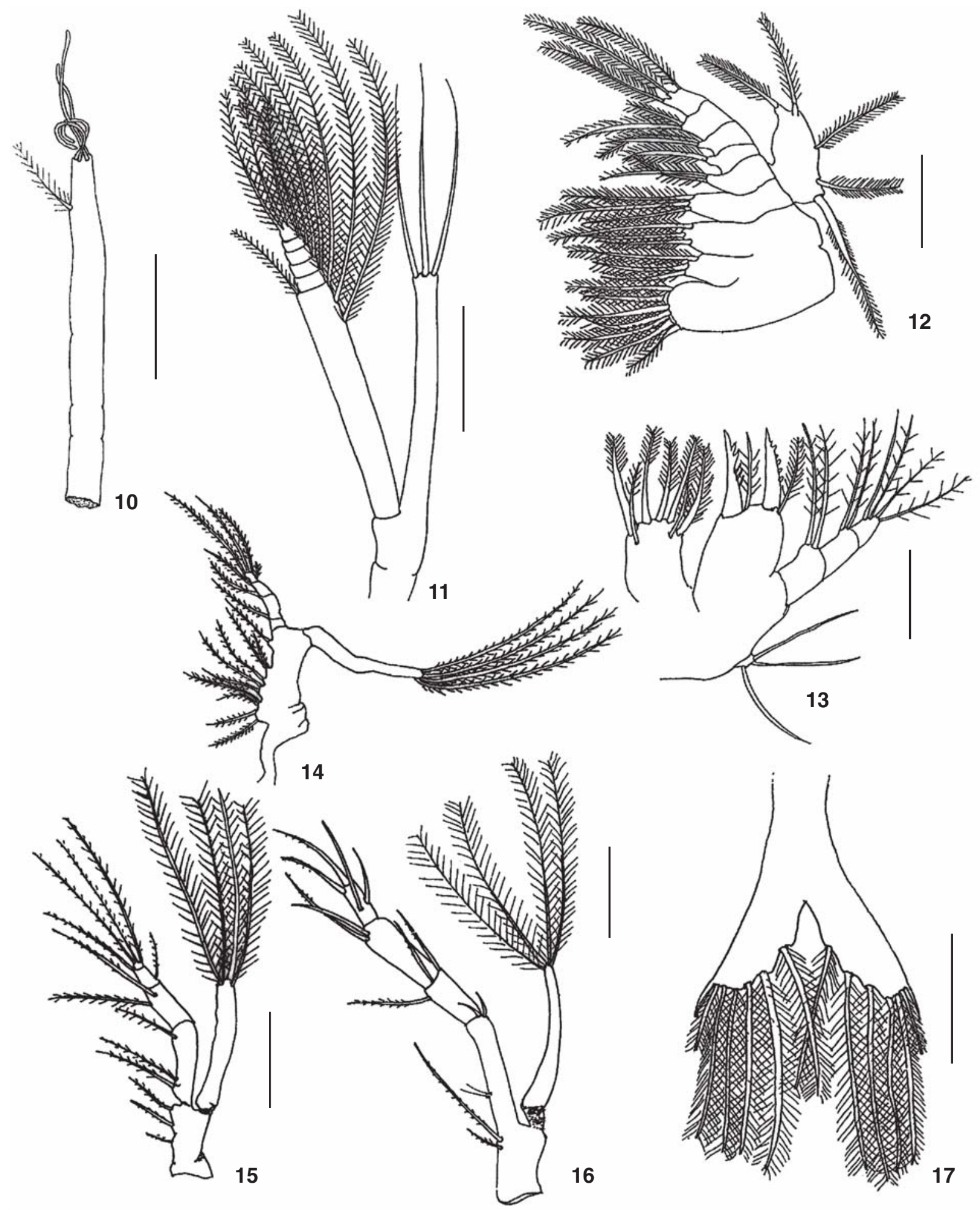

Figures 10-17. Enoplometopus antillensis, zoea I appendages: (10) antennule; (11) antenna; (12) maxillule; (13) maxilla; (14) $1^{\text {st }}$ maxilliped; (15) $2^{\text {nd }}$ maxilliped; (16) $3^{\text {rd }}$ maxilliped; (17) telson. Scale bar: 10 and 14-16 $=0.2 \mathrm{~mm}, 11-13=0.15 \mathrm{~mm}, 17=0.6 \mathrm{~mm}$.

Revista Brasileira de Zoologia 24 (2): 382-396, junho 2007 


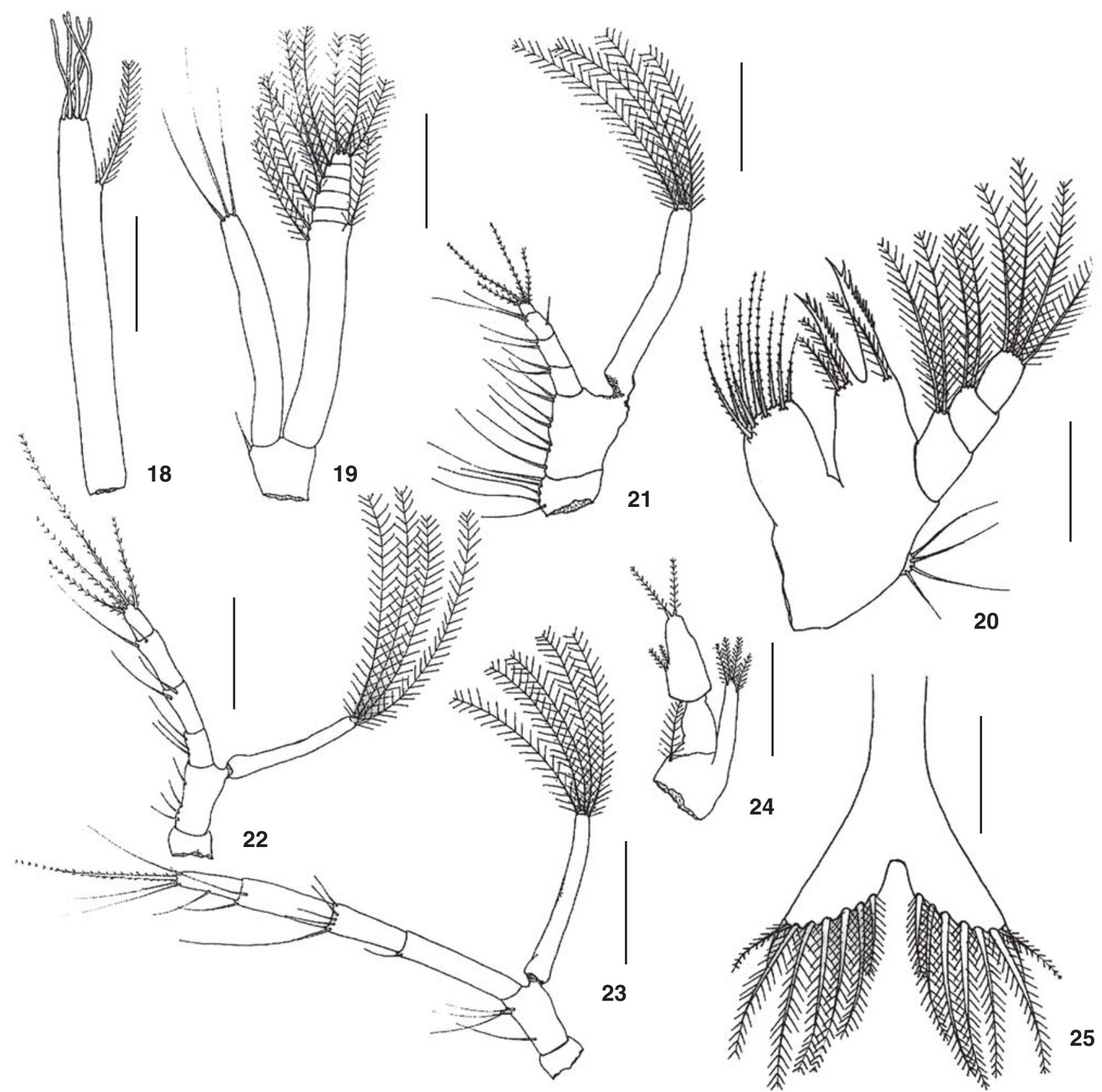

Figures 18-25. Enoplometopus antillensis, zoea II appendages: (18) antennule; (19) antenna; (20) maxillule; (21) $1^{\text {st }}$ maxilliped; (22) $2^{\text {nd }}$ maxilliped; (23) $3^{\text {rd }}$ maxilliped; (24) $1^{\text {st }}$ pereiopod; (25) telson. Scale bar: $18-20$ and $24=0.15 \mathrm{~mm}, 21-23=0.2 \mathrm{~mm}, 25=0.6 \mathrm{~mm}$.

arcuated with cutting margin of both fingers with short spines; exopod with 10 plumose setae.

Second pereiopod (Fig. 46): Endopod 4-segmented, arrangement of setation as illustrated; exopod with eight setae although absent in some examined specimens.

Third pereiopod (Fig. 47): endopod 4-segmented, shorter than second pereiopod, setation as illustrated; exopod with six setae but absent in some examined specimens. Fourth and Fifth pereiopods (Figs 48-49): Little developed with few setae, as illustrated.

Abdomen (Fig. 5): similar to the previous stage.

Telson (Fig. 50): posterior portion arcuated, with a strong

Revista Brasileira de Zoologia 24 (2): 382-396, junho 2007 


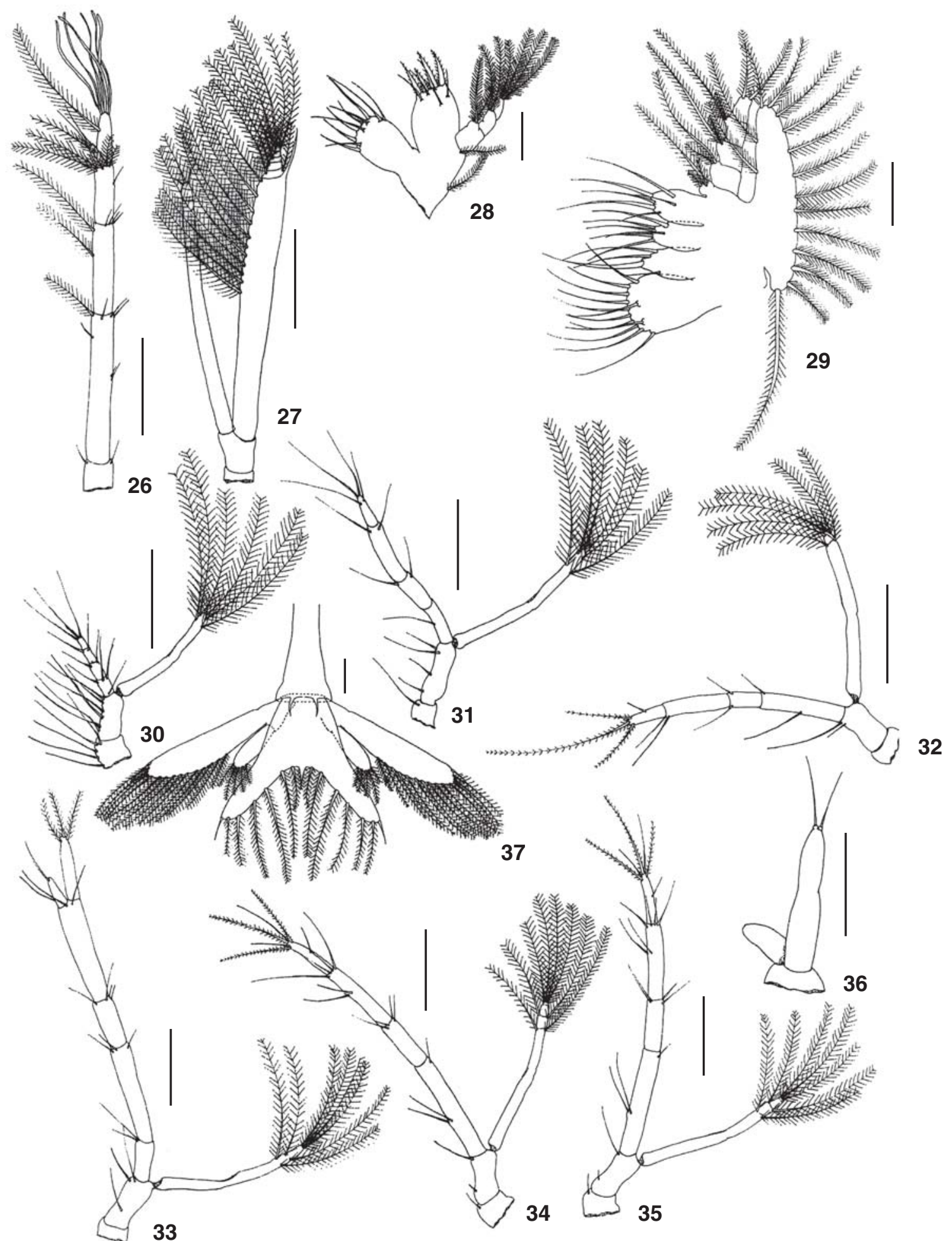

Figures 26-37. Enoplometopus antillensis, zoea III appendages: (26) antennule; (27) antenna; (28) maxillule; (29) maxilla; (30) $1^{\text {st }}$ maxilliped; (31) $2^{\text {nd }}$ maxilliped; (32) $3^{\text {rd }}$ maxilliped; (33) $1^{\text {st }}$ pereiopod; (34) $2^{\text {nd }}$ pereiopod; (35) $3^{\text {rd }}$ pereiopod; (36) $4^{\text {th }}$ pereiopod; (37) telson. Scale bar: $26-27$ and $30-35=0.3 \mathrm{~mm}, 28-29$ and $36=0.15 \mathrm{~mm}, 37=0.2 \mathrm{~mm}$.

Revista Brasileira de Zoologia 24 (2): 382-396, junho 2007 

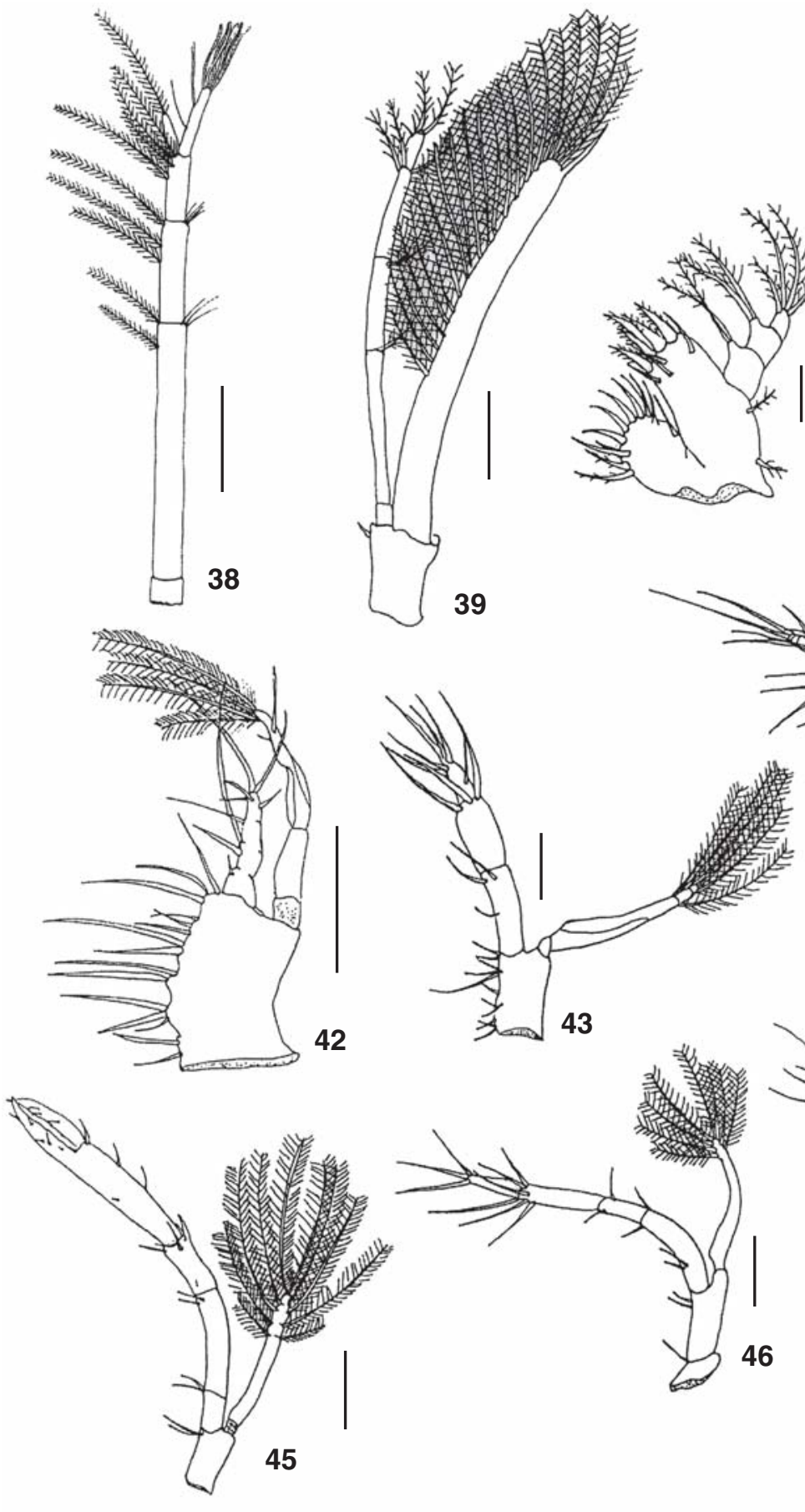

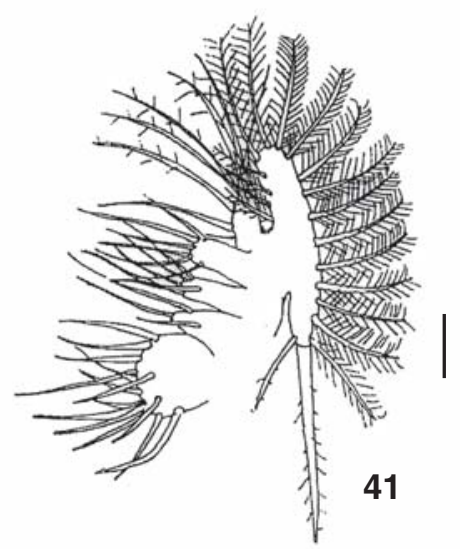

39
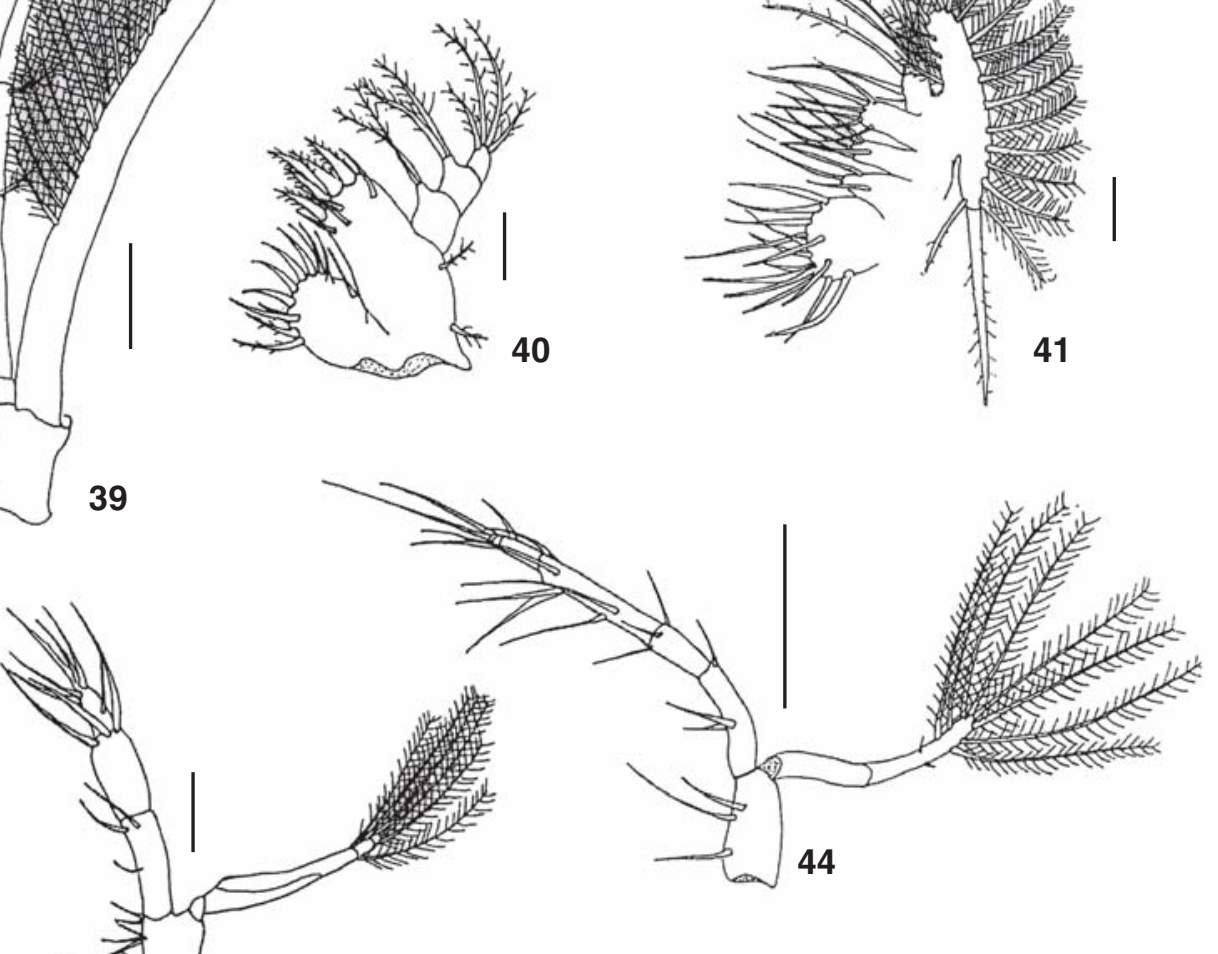

43

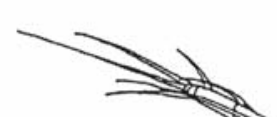

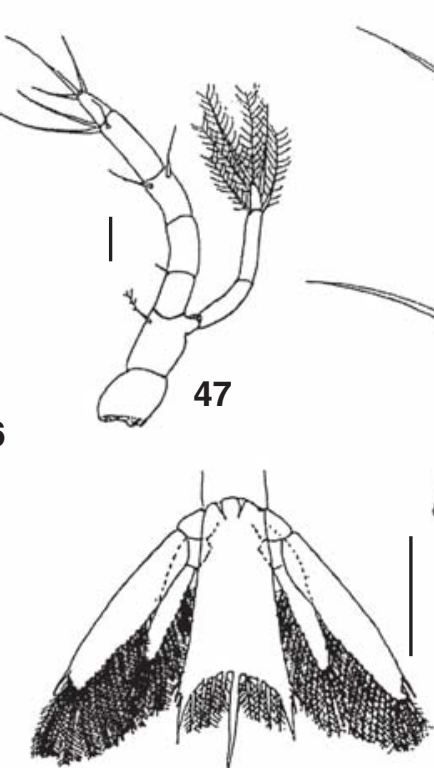

50

Figures 38-50. Enoplometopus antillensis, zoea IV appendages: (38) antennule; (39) antenna; (40) maxillule; (41) maxilla; (42) $1^{\text {st }}$ maxilliped; (43) $2^{\text {nd }}$ maxilliped; (44) $3^{\text {rd }}$ maxilliped; (45) $1^{\text {st }}$ pereiopod; (46) 2 nd pereiopod; (47) $3^{\text {rd }}$ pereiopod; (48) $4^{\text {th }}$ pereiopod; (49) $5^{\text {th }}$ pereiopod; (50) telson. Scale bar: $38-39,42-44,46-47$ and $49=0.3 \mathrm{~mm}, 40-41=0.1 \mathrm{~mm}, 45=0.5 \mathrm{~mm}, 48$ and $50=0.2 \mathrm{~mm}$. 


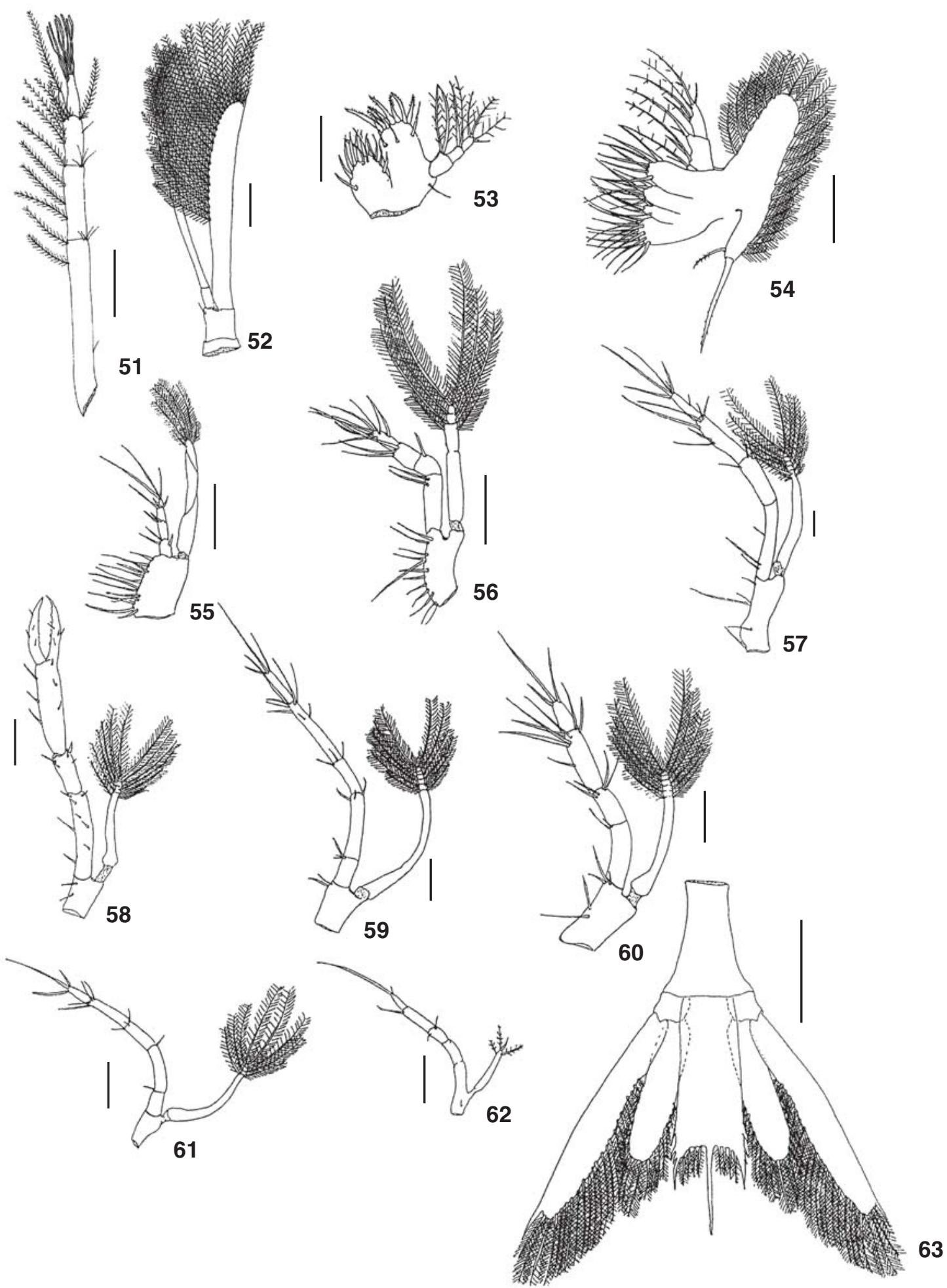

Figures 51-63. Enoplometopus antillensis, zoea V appendages: (51) antennule; (52) antenna; (53) maxillule; (54) maxilla; (55) $1^{\text {st }}$ maxilliped; (56) $2^{\text {nd }}$ maxilliped; (57) $3^{\text {rd }}$ maxilliped; (58) $1^{\text {st }}$ pereiopod; (59) $2^{\text {nd }}$ pereiopod; (60) $3^{\text {rd }}$ pereiopod; (61) $4^{\text {th }}$ pereiopod; (62) $5^{\text {th }}$ pereiopod; (63) telson. Scale bar in the figures: $51,53-57,59-62$ and $63=0.3 \mathrm{~mm}, 52=0.4 \mathrm{~mm}, 58=0.6 \mathrm{~mm}$.

Revista Brasileira de Zoologia 24 (2): 382-396, junho 2007 
and elongate median spine followed of $4+4$ inner setae, two strong spines in each arc extremity and $2+1$ spine on the outer margin; Uropod with exopod bearing 24-26 setae and 1 strong distal spine on outer margin; endopod with 21-23 setae.

\section{Zoea V (Fig. 6)}

Carapace (Fig. 6): length (CL) $2.88 \mathrm{~mm}(2.70-3.08 \mathrm{~mm})$. Antennule (Fig. 51): outer flagellum 2-segmented with $5+2$ aesthetascs.

Antenna (Fig. 52): exopod with 23-26 plumose setae; endopod longer than exopod with about 8-11 segments.

Maxillule (Fig. 53): basal endite with seven strong cuspidate and 3-4 simple setae; coxal endite with $6+5+3$ plumose setae.

Maxilla (Fig. 54): scaphognathite with 23-24+2 long plumose setae; basal and coxal endites as illustrated.

First maxilliped (Fig. 55): exopod with 4-6 natatory setae.

Second maxilliped (Fig. 56): exopod with eight natatory setae.

Third maxilliped (Fig. 57): exopod with 10-12 natatory setae.

First pereiopod (Fig. 58): similar to the previous stage; exopod with 12 plumose setae, absent in some examined specimens.

Second pereiopod (Fig. 59) and third pereiopod (Fig. 60): exopod with 12 natatory setae.

Fourth pereiopod (Fig. 61): endopod 4-segmented, distal segment ending in a long and bent spine; exopod with eight natatory setae.

Fifth pereiopod (Fig. 52): endopod 4-segmented, distal segment ending in a long and bent spine; exopod short with 45 natatory setae.

Telson (Fig. 63): posterior portion almost straight with a strong central spine and 4+4 inner setae; uropod with exopod bearing 31-32 setae and one distal spine; endopod with 23-25 setae.

\section{Zoea VI (Fig. 7)}

Carapace (Fig. 7): length (CL) $3.14 \mathrm{~mm}(2.65-3.70 \mathrm{~mm})$. Antennule (Fig. 64): inner flagellum 4-segmented ending in an acute distal seta; outer flagellum 4-segmented arranged in $2,2,1+1+2,2$ aesthetascs in the segmentations from proximal to distal, respectively.

Antenna (Fig. 65): exopod with 30+1 plumose setae; endopod with about 13 segments.

Maxillule (not illustrated): similar to the previous stage.

Maxilla (Fig. 66): scaphognathite with 38-39+5 long plumose setae; basal and coxal endites increasing in setae number on the lobes.

First maxilliped (Fig. 67), second maxilliped (Fig. 68), third maxilliped (Fig. 69) and first pereiopod (Fig. 70): similar to the previous stage.

Second pereiopod (Fig. 71) and third pereiopod (Fig. 72): exopod with 16 natatory setae.
Fourth pereiopod (Fig. 73) and fifth pereiopod (Fig. 74): similar to the previous stage.

Telson (Fig. 75): posterior portion subtriangular projecting afterwards; uropod with exopod bearing 37 setae and 1 strong distal spine; endopod with 32 plumose setae.

\section{Zoea VII (Fig. 8)}

Carapace (Fig. 8): length (CL) $3.42 \mathrm{~mm}$ (3.10-3.75 mm).

Antennule (Fig. 76): outer flagellum 4-segmented with increase of the aesthetascs, as illustrated; inner flagellum 5segmented.

Antenna (Fig. 77): exopod with 32-33 plumose setae; endopod longer than exopod with 22 segments.

Maxillule (Fig. 78): basal endite with seven strong cuspidate and 7-9 simple setae; coxal endite with approximately $10+12+6$ plumose setae.

Maxilla (Fig. 79): scaphognathite with 47-48 long plumose setae.

First maxilliped (Fig. 80): exopod with a row of seven lateral and six distal setae.

Second maxilliped (Fig. 81): exopod with 10 natatory setae.

Third maxilliped (Fig. 82): exopod with 14 natatory setae. First pereiopod (Fig. 83): exopod with 18 natatory setae. Second pereiopod (Fig. 84) and third pereiopod (Fig. 85): exopod with 14-16 natatory setae.

Fourth pereiopod (Fig. 86) and fifth pereiopod (Fig. 87): exopod with 10-12 natatory setae.

Telson (Fig. 88): posterior portion tapering posteriorly with the central spine more robust than previous stage and $4+4$ inner setae; uropod with exopod bearing 40 plumose setae; endopod with 36 plumose setae.

\section{Zoea VIII (Fig. 9)}

Carapace (Fig. 9): length (CL) $4.54 \mathrm{~mm}$ (4.60-4.48 mm), rostrum with $11+11$ denticles laterally.

Antennule (Fig. 89): outer flagellum with approximately 11-segmented; inner flagellum with approximately 17-segmented and four simple setae.

Antenna (Fig. 90): exopod with 43 plumose setae; endopod longer than exopod 30-segmented.

Maxillule (Fig. 91): basal endite with 6-7 strong serrulate and 14 simple setae; coxal endite with approximately $27+13+6$ plumose setae.

Maxilla (Fig. 92): scaphognathite with 60+13 long plumose setae.

First maxilliped (Fig. 93): exopod with a row of 13 lateral and three distal setae.

Second maxilliped (Fig. 94) and third maxilliped (Fig. 95): exopod with 16 natatory setae.

First pereiopod (Fig. 96) and second pereiopod (Fig. 97): exopod with 20-22 natatory setae.

Third pereiopod (Fig. 98): exopod with 20 natatory setae.

Revista Brasileira de Zoologia 24 (2): 382-396, junho 2007 


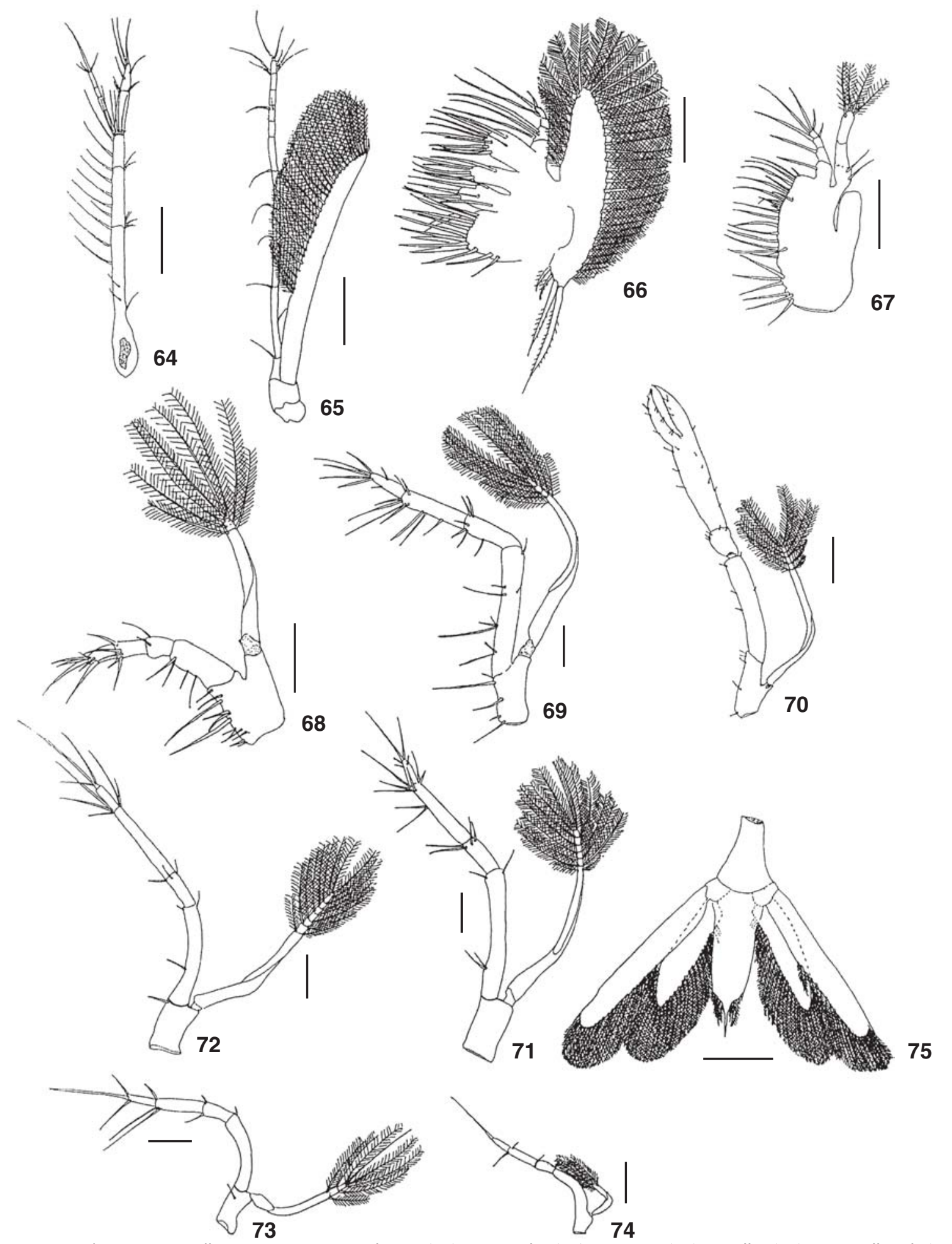

Figures 64-75. Enoplometopus antillensis, zoea VI appendages: (64) antennule; (65) antenna; (66) maxilla; (67) $1^{\text {st }}$ maxilliped; (68) $2^{\text {nd }}$ maxilliped; (69) $3^{\text {rd }}$ maxilliped; (70) $1^{\text {st }}$ pereiopod; (71) $2^{\text {nd }}$ pereiopod; (72) $3^{\text {rd }}$ pereiopod; (73) $4^{\text {th }}$ pereiopod; (74) $5^{\text {th }}$ pereiopod; (75) telson. Scale bar: $64-65$ and $70=0.6 \mathrm{~mm}, 66-69$ and $71-75=0.3 \mathrm{~mm}$.

Revista Brasileira de Zoologia 24 (2): 382-396, junho 2007 


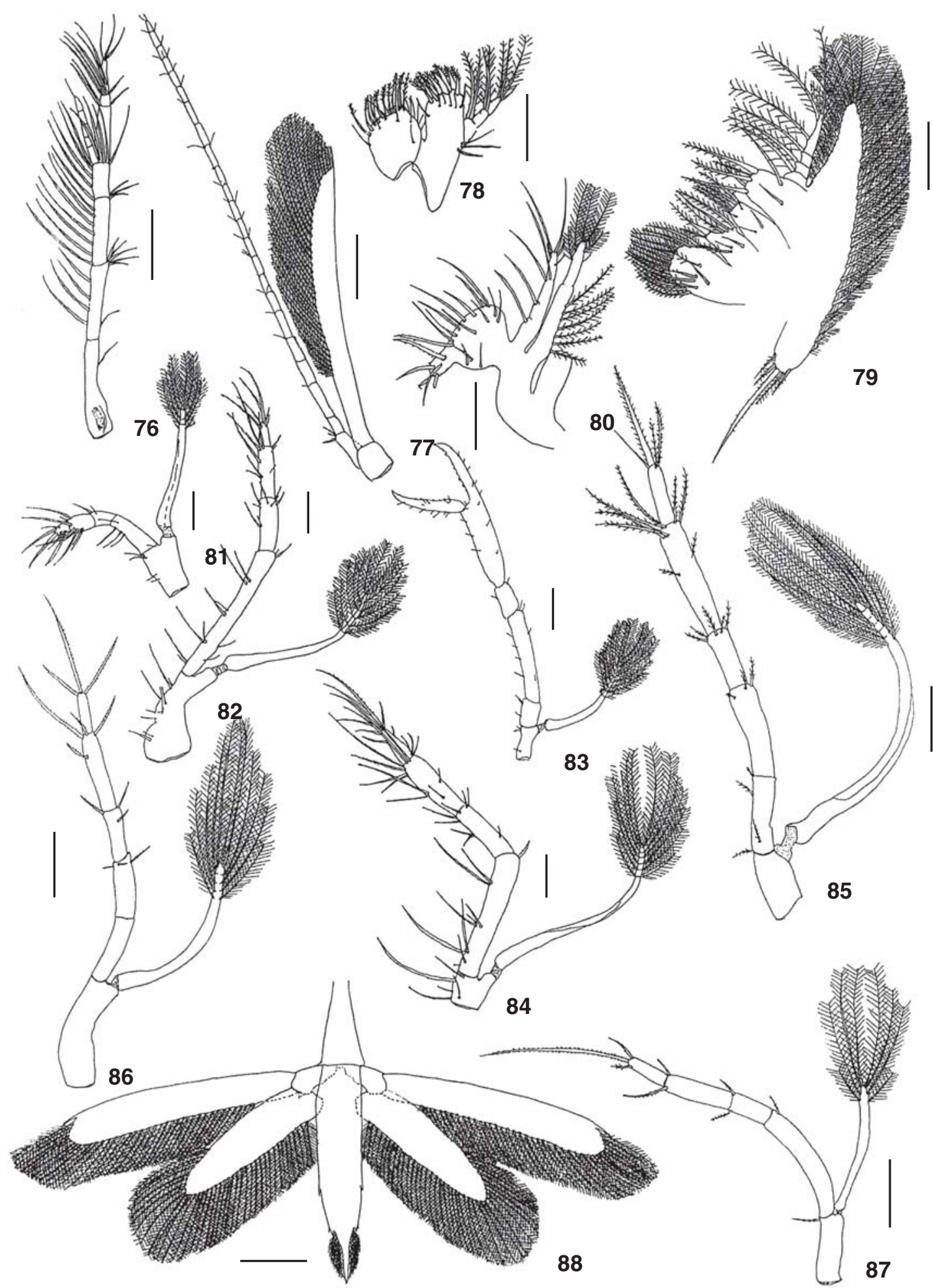

Figures 76-88. Enoplometopus antillensis, zoea VII appendages: (76) antennule; (77) antenna; (78) maxillule; (79) maxilla; (80) $1^{\text {st }}$ maxilliped; (81) $2^{\text {nd }}$ maxilliped; (82) $3^{\text {rd }}$ maxilliped (83) $1^{\text {st }}$ pereiopod; (84) $2^{\text {nd }}$ pereiopod; (85) $3^{\text {rd }}$ pereiopod; (86) $4^{\text {th }}$ pereiopod; (87) $5^{\text {th }}$ pereiopod; (88) telson. Scale bar: 76-77, 83 and $88=0.6 \mathrm{~mm}, 78-82$ and $84-87=0.3 \mathrm{~mm}$. 


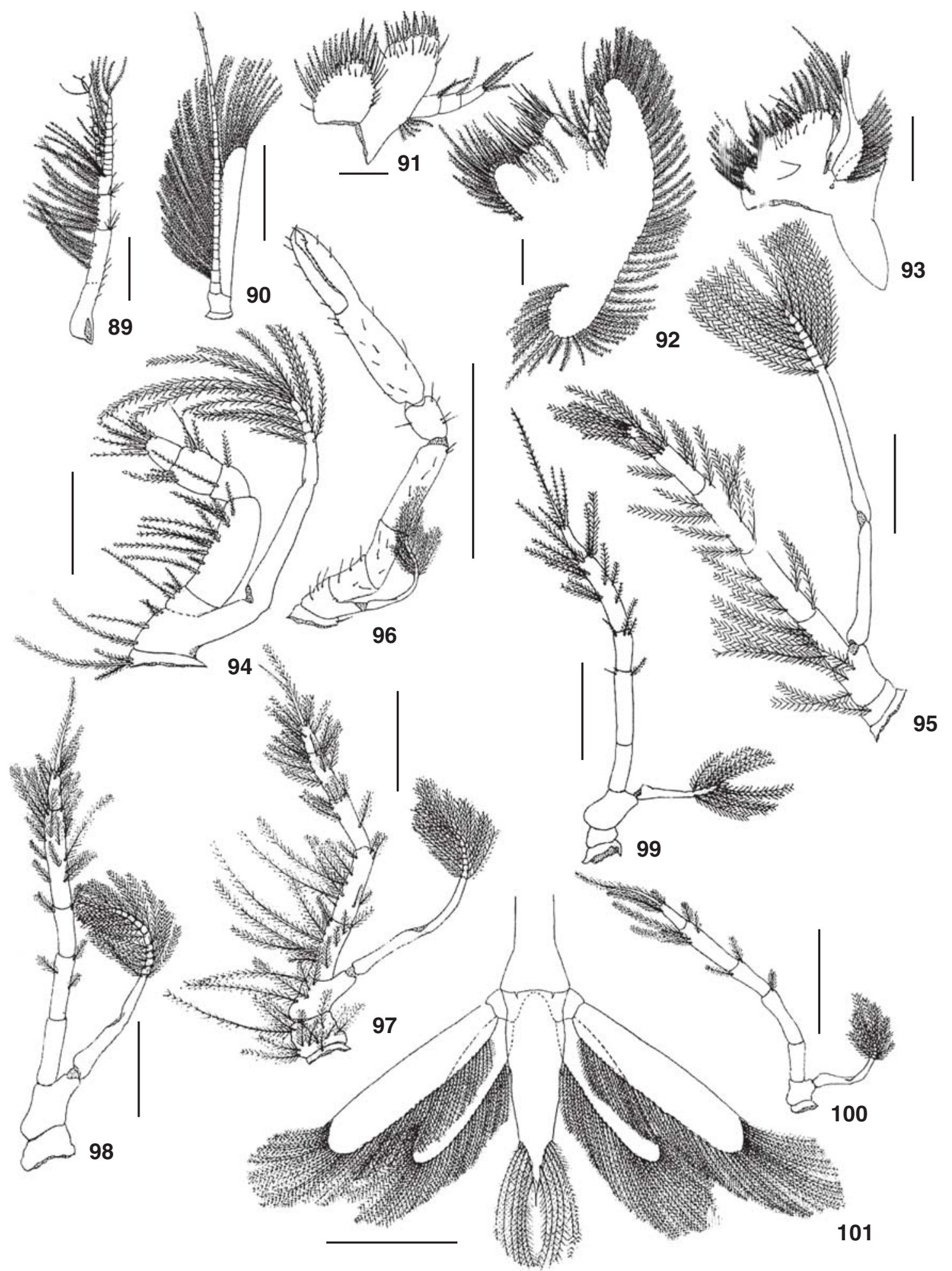

Figures 89-101. Enoplometopus antillensis, zoea VIII appendages: (89) antennule; (90) antenna; (91) maxillule; (92) maxilla; (93) $1^{\text {st }}$ maxilliped; (94) $2^{\text {nd }}$ maxilliped; (95) $3^{\text {rd }}$ maxilliped (96) $1^{\text {st }}$ pereiopod; (97) $2^{\text {nd }}$ pereiopod; (98) $3^{\text {rd }}$ pereiopod; (99) $4^{\text {th }}$ pereiopod; (100) $5^{\text {th }}$ pereiopod; (101) telson. Scale bar: $89-90=0.9 \mathrm{~mm}, 91-92=0.2 \mathrm{~mm}, 93-94=0.3 \mathrm{~mm}, 95$ and $97-100=0.6 \mathrm{~mm}, 96$ and $101=1.2 \mathrm{~mm}$.

Revista Brasileira de Zoologia 24 (2): 382-396, junho 2007 
Fourth pereiopod (Fig. 99) and fifth pereiopod (Fig. 100): exopod with 14-16 natatory setae.

Telson (Fig. 101): posterior portion 6+6 inner setae; exopod with 50 plumose setae; endopod with 40 plumose setae.

\section{DISCUSSION}

In the laboratory, the larvae of E. antillensis moulted seven times comprising eight larval stages. Unfortunately, no larvae were able develop to the postlarval stage. The intermoulting period of each stage averaged from 8-12 days. Another attempt at rearing was accomplished by Iwata et al. (1991) for $E$. occidentalis, progressing also through eight larval stages, but they also were been unsuccessful in moulting into juvenile stage.

Morphological results of each zoeal stage of $E$. antillensis are shown in table I. A comparison of the morphological characteristics of E. antillensis described at the present study with previous descriptions of Enoplometopidae larvae was limited to the study of Iwata et al. (1991) for E. occidentalis. The most notable distinction between these two species by that $E$. antillensis lacks the pereiopods in the prezoea (Fig. 1), these structures only appearing in the zoea III, while for E. occidentalis, these appendages are well developed from the prezoea stage (mainly the pereiopod I, already cheleted) (Tabs I and II). Some distinctions are also observed in the development of the pereiopods. In $E$. antillensis, the pereiopod I arises as a subchelate structure in stage III and it becomes entirely formed only in stage IV. The pleopods of E. antillensis and E. occidentalis are not observed in the stage VIII (Tab. II).

Many other morphological distinctions are observed between these two species when comparing their morphological features in the stage II. The endopods of the maxillule and maxilla of E. occidentalis are unsegmented, whereas in the $E$. antillensis they are segmented. In this stage, the arrangement of setation of these species is rather different in the appendages mainly those of endopod of maxillule, scaphognathite of maxilla and telson (Tab. III).

These facts suggest that a noticeable distinction may occur in the larval development of Enoplometopidae species. Fur-

Table I. Main morphological characteristics of zoeal stages of Enoplometopus antillensis.

\begin{tabular}{|c|c|c|c|c|c|c|c|c|c|c|c|}
\hline \multirow{3}{*}{ Stages } & \multirow{3}{*}{$\begin{array}{l}\text { Mean carapace length } \\
(\mathrm{mm})\end{array}$} & \multirow{3}{*}{$\begin{array}{c}\text { Maxilla } \\
\text { scaphognathite }\end{array}$} & \multirow{3}{*}{$\begin{array}{l}\text { Antenna } \\
\text { (Exopod) }\end{array}$} & \multicolumn{8}{|c|}{ Number of natatory setae } \\
\hline & & & & \multicolumn{3}{|c|}{ Maxilliped } & \multicolumn{5}{|c|}{ Pereiopod } \\
\hline & & & & $1^{\text {st }}$ & $2^{\text {nd }}$ & $3^{\text {rd }}$ & $1^{\text {st }}$ & $2^{\text {nd }}$ & $3^{\text {rd }}$ & $4^{\text {th }}$ & $5^{\text {th }}$ \\
\hline $\mathrm{I}$ & 1.89 & $4+1$ & $(8-9)+1$ & 4 & 4 & 4 & - & - & - & - & - \\
\hline II & 2.24 & $4+1$ & $(8-9)+1$ & 4 & 4 & 5 & $3-4$ & - & - & - & - \\
\hline III & 1.96 & $18+1$ & $22-23$ & 6 & 6 & 8 & 8 & 8 & 7 & 2 & - \\
\hline IV & 2.23 & $18-21$ & $22-23$ & $4+2$ & 6 & 8 & 10 & 8 & 6 & 4 & - \\
\hline V & 2.88 & $23-24+2$ & $23-26$ & $4-6$ & 8 & $10-12$ & 12 & 12 & 12 & 8 & $4-5$ \\
\hline VI & 3.14 & $38-39+5$ & $30+1$ & 6 & 8 & $10-12$ & 12 & 16 & 16 & 8 & $4-5$ \\
\hline VII & 3.42 & $47-48$ & $32-33$ & $7+6$ & 10 & 14 & 18 & $14-16$ & $14-16$ & $10-12$ & $10-12$ \\
\hline VIII & 4.54 & $60+13$ & 43 & $13+3$ & 16 & 16 & $20-22$ & $20-22$ & 20 & $14-16$ & $14-16$ \\
\hline
\end{tabular}

Table II. A comparison between the main characteristics of each zoeal stage of $E$. antillensis (present study) and E. occidentalis described by IWATA et al. (1991).

\begin{tabular}{cll}
\hline Stage & \multicolumn{1}{c}{ E. antillensis (Present study) } & \multicolumn{1}{c}{ E. occidentalis (IWATA et al. 1991) } \\
\hline Prezoea & Lack pereiopods & Pereiopods I-III present Pereiopod I chelate \\
I & pereiopod absent & $\begin{array}{l}\text { Pereiopods I-III present } \\
\text { Pereiopod I chelate }\end{array}$ \\
II & Only pereiopod I present, but rudimentary & Pereiopods I-IV present \\
III & Pereiopods I-V present & Pereiopods I-V present \\
& Pereiopod I subchelate & Pereiopod V small \\
IV & Pereiopods IV and V small & Pereiopods I-V present \\
V & Pleopods absent & Pereiopods I-V present \\
VI & Pleopods absent & Pleopods absent \\
VII & Pleopods absent & Pleopods absent \\
VIII & Pleopods absent & Pleopods absent \\
\hline
\end{tabular}


Table III. Comparison of main larval characters of the second zoea stage between $E$. antillensis and $E$. occidentalis described by IwATA et al. (1991).

\begin{tabular}{|c|c|c|c|}
\hline \multicolumn{2}{|c|}{ Appendages } & \multirow[t]{2}{*}{ E. antillensis (Present study) } & \multirow{2}{*}{$\frac{\text { E. occidentalis (IWATA et al. 1991) }}{4.5}$} \\
\hline Size & Total length $(\mathrm{mm})$ & & \\
\hline \multirow[t]{2}{*}{ Antenna } & Endopod setae & 3 setae & 3 setae \\
\hline & Exopod setae & 10 inner, 1 terminal & 14 inner, 1 teminal \\
\hline Maxillule & Endopod & 3 -segmented with $(2+2)+2+2$ setae & Unsegmented, 5 setae \\
\hline \multirow[t]{2}{*}{ Maxilla } & Endopod & 4-segmented & Unsegmented, 4 setae \\
\hline & Scaphognathite & $4+1$ setae & 13 setae \\
\hline \multirow[t]{2}{*}{ Maxilliped I } & Endopod & 4-segmented & Unsegmented \\
\hline & Exopod & 4 setae & Rudimentary with 2 setae \\
\hline \multirow[t]{2}{*}{ Maxilliped II } & Endopod & 4-segmented & 3-segmented \\
\hline & Exopod & 4 setae & Rudimentary \\
\hline \multirow[t]{2}{*}{ Maxilliped III } & Endopod & 4-segmented & 3-segmented \\
\hline & Exopod & 5 setae & 7 setae \\
\hline Pereiopod & Endopod & $1-5$ ( $1^{\text {st }}$ undeveloped $)$ & $1 \sim 5\left(1^{\text {st }}\right.$ chelate and well developed \\
\hline Abdomen & Lateral spine & $+($ somite 6$)$ & $+($ somite 5$)$ \\
\hline \multirow[t]{3}{*}{ Telson } & Processes & $7+7$ & $8+8$ \\
\hline & Endopod & absent & Absent \\
\hline & Exopod & absent & Absent \\
\hline
\end{tabular}

ther studies of phylogeny and/or molecular biology studies will be needed to elucidate the correct taxonomic position of the Enoplometopidae species. Ahyong \& O’Meally (2004) reported a comprehensive study on the phylogeny of decapods using both molecular biology and morphological characters in which the genus Enoplometopus is included. However, only the species $E$. occidentalis was used in DNA mitochondrial analysis. Scientific data of phylogenetic study is lacking for other species.

\section{ACKNOWLEDGMENT}

The authors wish to thank Dr. Gil Penha Lopes of the Laboratório Maritimo da Guia, FCUL \& IMAR for sending his oral presentation in the Marine Ornamental' 04.

\section{REFERENCES}

Ahyong, S.T. \& D. O'meally. 2004. Phylogeny of the Decapoda Reptantia: Resolution using three molecular loci and morphology. Raffles Bulletin of Zoology 52 (2): 673-693.

Imata, Y; H. Sugrta; Y. Deguchi \& F.I. Kamemoto. 1991. The early larval development of the tropical reef lobster Enoplometopus occidentalis (Decapoda, Axiidae) reared in the laboratory. Researches on Crustacea 20: 1-15.

Received in 18.X.2006; accepted in 07.V.2007.
KITTAKA, J. 1994. Culture of phyllosomas of spiny lobster and its application to studies of larval recruitment and aquaculture. Crustaceana 66 (3): 257-270.

Martin, J.W. \& G.E. Davis. 2001. An updated classification of the recent Crustacea. Natural History Museum of Los Angeles County, Science Series 39: 1-124.

Merino, S.E. \& J.A. LindLey. 2003. First record of Enoplometopus callistus (Crustacea: Decapoda: Nephropidae) in the Cape Verde Islands. Journal of the Marine Biological Association of the United Kingdom 83: 1233-1234.

Penha-Lopes, G.; A.L. Rhyne; J. Figueredo; J. Lin \& L. Narciso. 2006. Can larvae produced from stored sperm in the ornamental crab Mithraculus forceps (A. Milne Edwards, 1875) (Decapoda: Brachyura: Majidadae) be used in aquaculture? Aquaculture 257 (1-4): 282-286.

Poupin, J. 2003. Reef lobster Enoplometopus A. Milne Edwards, 1862 from French Polynesia, with a brief revision of the genus (Crustacea, Decapoda, Enoplometopidae). Zoosystema 25 (4): 643-664.

Rhyne, A.L.; G. Penha-Lopes \& J. Lin. 2005. Growth, development, and survival of larval Mithraculus sculpus (Lamarck) and Mithraculus forceps (A. Milne Edwards) (Decapoda: Brachyura: Majidae): economically important marine ornamental crabs. Aquaculture 245: 183-191. 